\title{
Modification of lithium titanate spinel by d-electron metals
}

\author{
Danuta Olszewska ${ }^{1, *}$ and Anna Rutkowska ${ }^{1}$ \\ ${ }^{1}$ AGH University of Science and Technology, Faculty of Energy and Fuels, al. A. Mickiewicza 30, \\ 30-059 Cracow, Poland
}

\begin{abstract}
A simply and cheap solid state synthesis was used to produce powders of spinel phase $\mathrm{Li}_{4-\mathrm{x}} \mathrm{Cu}_{\mathrm{x}} \mathrm{Ti}_{5} \mathrm{O}_{12}$, where $0 \leq \mathrm{x} \leq 0.2$, with crystallite size in $\sim 890$ nanometers range. The as-prepared samples were verified by scanning electron microscopy and X-ray diffraction. The electrochemical performance of these samples was examined by galvanostatic and voltamperometric tests. To determine transport properties an impedance spectroscopy tests were obtained. These measurements showed excellent high-rate performance and remark- ably good cyclability of the fabricated powders. Capacity retention in $\mathrm{Li}_{3.85} \mathrm{Cu}_{0.15} \mathrm{Ti}_{5} \mathrm{O}_{12}$ has $77 \%$ theoretical capacity after raise the discharge current from $1 \mathrm{C}$ to $10 \mathrm{C}$ and there is less than $2 \%$ of capacity loss after 50 charge/discharge cycles at $1 \mathrm{C}$ current rate.
\end{abstract}

\section{Introduction}

The world population is constantly growing, particularly in undeveloped countries, they usually consume energy in improper way. It is caused by having an inefficient energy systems and outdated devices. However, well developed countries are equally guilty. Modern society buy more and more electronic devices, drive power electric vehicles, industry is based on electricity instead of human work. All of this operations cause that world's energy sources are still decreasing. Moreover, some of the most important issues are global warming and air pollution, which are connected with combustion of traditional fuels [1]. The key to replacement of fossil fuels and traditional energy sources is to create effective systems of energy storage from renewable sources $[2,3]$. Energy storage technologies - such as various types of batteries, electrochemical capacitors, pumped hydro, compressed air energy storage, flywheels etc., are very useful for many applications: backup power, energy management, load levelling, frequency regulation, voltage support, and grid stabilization [4, 5]. Unfortunately, not every type of storage is suitable for every type of application because of its special characteristics. An energy storage system should be safe, reliable, as cheap as possible and acceptable to industry. Lithium-ion batteries seem to be an attractive candidate to this goal [6]. Li-ion batteries have high gravimetric and volumetric energy, high power density and long life $[7,8]$. Lithium titanate spinel $-\mathrm{Li}_{4} \mathrm{Ti}_{5} \mathrm{O}_{12}$ (sign. LTO), has very good electrochemical properties and it is an attractive anode material in Li-ion batteries [6,9]. LTO has high working potential $\left(\sim 1.55 \mathrm{~V}\right.$ vs. $\left.\mathrm{Li} / \mathrm{Li}^{+}\right)$due to the redox couple of $\mathrm{Ti}^{3+} / \mathrm{Ti}^{4+}[5,10]$. It

\footnotetext{
*Corresponding author: dolszew@agh.edu.pl
} 
avoids the formation of SEI, contrary to graphite. Lithium titanate is environmentally friendly, inexpensive, of long cycle life, overcharge resistance and wide temperature work range [11]. The most crucial issue is the fact that LTO is a zero-strain material, what means that during the charge/discharge process it doesn't show any change of lattice parameter at all [12]. According to the reaction:

$$
3 \mathrm{Li}+\mathrm{Li}_{4} \mathrm{Ti}_{5} \mathrm{O}_{12}=\mathrm{Li}_{7} \mathrm{Ti}_{5} \mathrm{O}_{12}
$$

theoretical nondoped LTO capacity is around $175 \mathrm{mAh} \cdot \mathrm{g}^{-1}$. Despite all of these advantages $\mathrm{Li}_{4} \mathrm{Ti}_{5} \mathrm{O}_{12}$ is an insulator with low electronic conductivity $\left(10^{-13} \mathrm{Scm}^{-1}\right)$ [13]. Furthermore, spinel $\mathrm{Li}_{4} \mathrm{Ti}_{5} \mathrm{O}_{12}$ shows a very small volume variation during the charge/discharge process, consequently resulting in excellent cycle stability. Due to this fact, numerous researchers have been trying to improve its transport properties, by going to nanoscale [7, 14-20] or/and doping [21-27]. The second way is to dope with cations/anions in $\mathrm{Li}$, $\mathrm{Ti}$ or $\mathrm{O}$ site; modification with d-electron metal could enhance electronic conductivity and reduce the electrode polarization. In this paper spinel was doped $\mathrm{Li}_{4} \mathrm{Ti}_{5} \mathrm{O}_{12}$ with $\mathrm{Cu}^{2+}$ ions.

\section{Experimental}

\subsection{Synthesis of main electrode materials}

All samples were prepared using a one-step solid-state reaction method. In all of synthesis processes $\mathrm{Li}_{2} \mathrm{CO}_{3}$ (Aldrich, 99.8\%), and $\mathrm{TiO}_{2}$-anatase (Acros, 99+\%) powders as $\mathrm{Li}^{+}$and $\mathrm{Ti}^{4+}$ sources were used. Moreover, in some powders $\mathrm{CuO}$ (Acros, 99+\%) as a $\mathrm{Cu}^{2+}$ source was used. The mixed reactants were ball-milled for $20 \mathrm{~min}$ with a propanol (POCH, pure) added. After drying, powders were calcinated at $900^{\circ} \mathrm{C}$ for $4 \mathrm{~h}$ in a tube furnace in air atmosphere. In order to eliminate $\mathrm{TiO}_{2}$ phase in samples, we used $105 \%$ of calculated stoichiometric $\mathrm{Li}_{2} \mathrm{CO}_{3}$ weight.

\subsection{Structure and morphology}

The phase characteristics and structural studies of the materials were determined by X-ray diffraction in $10-110 \mathrm{deg}$ range with $\mathrm{CuK} \alpha$ radiation $(\lambda=1.5406 \AA)$, using Panalytical Empyrean diffractometer. Rietveld analysis of XRD data were done using GSAS/EXPGUI set of software [28-30]. Morphology and structure of samples were analyzed by NanoSEM 200 FEI scanning electron microscope equipped with low vacuum detector (LVD).

\subsection{Preparation of lithium-ion batteries}

The electrochemical tests were prepared using CR2032 coin-type cells. The working electrodes were prepared by pasting a slurry containing $70 \mathrm{wt} . \%$ active material, $15 \mathrm{wt} . \%$ graphite, $10 \mathrm{wt} . \%$ carbon black and $5 \mathrm{wt} . \%$ polyvinylidene fluoride (PVDF) dissolved in Nmethyl-2-pyrrolidone onto an aluminum foil. After coating, the slurry was dried in a vacuum dryer in $70^{\circ} \mathrm{C}$ for $1 \mathrm{~h}$. Batteries were assembled in the glove-box (UNILAB, M. Braun) under argon atmosphere with controlled oxygen and water vapor pressure $(<0.1 \mathrm{ppm})$ using a metal lithium foil as a counter electrode and $1 \mathrm{M} \mathrm{LiPF}_{6}$ solution in the $1: 1$ mixture of ethylene carbonate (EC) and dimethyl carbonate (DEC) as a electrolyte. 


\subsection{Electrochemical and transport measurements}

The electrochemical characterizations were obtained using galvanostatic charge/discharge cycles at different rates over a voltage range of 1.3-2.2 V. The $\mathrm{C}$ rate was calculated based on tested-electrode weight and theoretical capacity of LTO. Cells were tested at computercontrolled galvanostat KEST $32 \mathrm{k}$ multichannel and ATLAS measurement. All of electrochemical tests were carried out at room temperature. Cyclic voltammetry studies were carried out using ATLAS measurement with scanning rates in the range of $0.01-5 \mathrm{mV} \mathrm{s}^{-1}$ and in 1.3-2.0 V voltage range.

Electrical conductivity of the synthesized materials was measured on disk-shaped sinters by impedance spectroscopy method in a frequency range of $10^{-1}$ to $10^{6} \mathrm{~Hz}$, using Solartron SI 1260 Frequency Response Analyzer. The obtained data were analyzed using ZView 2.0 software (Scribner Associates).

\section{Results and discussion}

\subsection{Structure}

Names of samples with their theoretical calculated capacity and volume of cells are shown in Table 1. In this Table synthesis conditions are presented as well. Fig. 1. presents the diffraction patterns of the tested powders. Fig. 2 presents SEM images of sample $\mathrm{Li}_{3.85} \mathrm{Cu}_{0.15} \mathrm{Ti}_{5} \mathrm{O}_{12}$ : magnification $\cdot 10000$ (left) and $\cdot 50000$ (right) respectively.

Table 1. Specification of $\mathrm{Li}_{4} \mathrm{Ti}_{5} \mathrm{O}_{12}$ samples doped with copper. Chemical formula, preparation conditions, structure parameters (space group, cell volume) and theoretical capacity.

\begin{tabular}{|c|c|c|c|c|c|c|}
\hline & $\underset{ت}{\stackrel{0}{0}}$ & 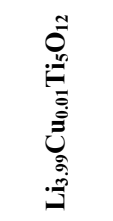 & 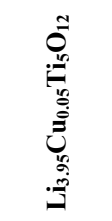 & 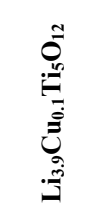 & 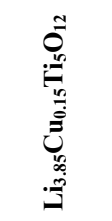 & 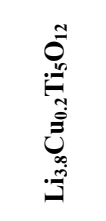 \\
\hline $\mathrm{Cu}$ content & 0 & 0.01 & 0.05 & 0.1 & 0.15 & 0.2 \\
\hline $\begin{array}{l}\text { Theoretical capacity } \\
{[\mathrm{mAh} / \mathrm{g}]}\end{array}$ & 175.17 & 174.93 & 174.07 & 173.01 & 171.95 & 170.93 \\
\hline Cell volume $\left[\AA^{3}\right]$ & 584.35 & 584.54 & 584.53 & 581.67 & 584.79 & 584.74 \\
\hline \multicolumn{7}{|c|}{ Preparation conditions } \\
\hline Substrates & $\mathrm{Li}_{2} \mathrm{CO}_{3}+\mathrm{TiO}_{2}$ & \multicolumn{5}{|c|}{$\mathrm{Li}_{2} \mathrm{CO}_{3}+\mathrm{TiO}_{2}+\mathrm{CuO}$} \\
\hline Milling time [min] & \multicolumn{6}{|c|}{20} \\
\hline Temperature $\left[{ }^{\circ} \mathrm{C}\right]$ & \multicolumn{6}{|c|}{900} \\
\hline Heating time $[\mathrm{h}]$ & \multicolumn{6}{|c|}{4} \\
\hline
\end{tabular}


In order to detect phase composition in the sintered material, powders were examined in room-temperature by X-ray diffraction. The study demonstrates that the samples of $\mathrm{Li}_{4-\mathrm{x}} \mathrm{Cu}_{\mathrm{x}} \mathrm{Ti}_{5} \mathrm{O}_{12}(\mathrm{x}=0-0.2)$ have similar phase composition. We can observe the most intensive peak at the $2 \theta$ of $18.4^{\circ}, 43.3^{\circ}, 35.6^{\circ}$ and $62.8^{\circ}$, which can be well assigned to the characteristic diffraction peaks of the cubic $\mathrm{Li}_{4} \mathrm{Ti}_{5} \mathrm{O}_{12}$ spinel-type phase with the $F d$ - $3 m$ space group, with the planes at (111), (220), (311), (222), (400), (331), (422), (333), (511), (440), (531) and (444) - ICDD 04-007-9267. The XRD patterns show several impurity peaks at $2 \theta$ of $18.5^{\circ}, 20.5^{\circ}, 43.6^{\circ}$ and $43.9^{\circ}$ which can correspond with the diffraction peak of the monoclinic-type $\mathrm{Li}_{2} \mathrm{TiO}_{3}$ with the $\mathrm{C} 2 / \mathrm{c}$ space group, listed in the ICDD 04-009-2812. The maximum amount of $\mathrm{Li}_{2} \mathrm{TiO}_{3}$-impurities were obtained in $\mathrm{Li}_{3.95} \mathrm{Cu}_{0.05} \mathrm{Ti}_{5} \mathrm{O}_{12}$ samples and it was at 12 wt. \% range. The highest purity is in the $\mathrm{Li}_{3.85} \mathrm{Cu}_{0.15} \mathrm{Ti}_{5} \mathrm{O}_{12}$ powder, where there is $6.5 \mathrm{wt} . \%$ of $\mathrm{Li}_{2} \mathrm{TiO}_{3}$ in powder. Other samples have similar amount of impurities from $8 \mathrm{wt} . \%$ to $11 \mathrm{wt} . \%$. In the as-prepared powders there is no $\mathrm{TiO}_{2}$ (rutile) phase, which was observed in the our previous work. The lack of $\mathrm{TiO}_{2}$ is caused by over-stoichiometric amount of $\mathrm{Li}_{2} \mathrm{CO}_{3}$ in mix of the precursors. All of this XDR pattern analyzes were obtained using a mathematical Rietveld method with very satisfying value of $\chi^{2}=5 \pm 1.5$. According to the literature [28], the phase transition from spinel phase to the structure of rock salt causes only a slight shrinkage of the lattice parameter, of $8.3595 \AA-8.3538 \AA$, with only a $0.2 \%$ change in cell volume. The cell parameters of the prepared powders fall within the range 8.3605 $8.3625[\AA]$. The elementary cell volume is in the range of 584.35-584.58 [ $\left.\AA^{3}\right]$. This confirms that the structural parameters correspond with the literature.

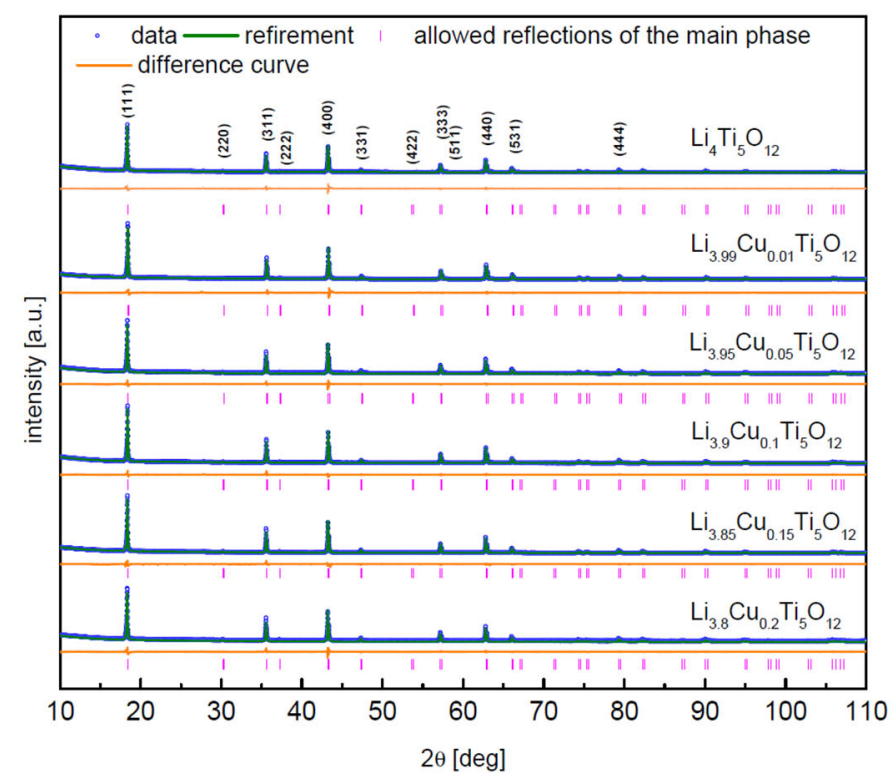

Fig. 1. X-ray diffraction patterns of samples $\mathrm{Li}_{4} \mathrm{Ti}_{5} \mathrm{O}_{12}, \mathrm{Li}_{3.99} \mathrm{Cu}_{0.01} \mathrm{Ti}_{5} \mathrm{O}_{12}, \mathrm{Li}_{3.95} \mathrm{Cu}_{0.05} \mathrm{Ti}_{5} \mathrm{O}_{12}$, $\mathrm{Li}_{3.9} \mathrm{Cu}_{0.1} \mathrm{Ti}_{5} \mathrm{O}_{12}, \mathrm{Li}_{3.85} \mathrm{Cu}_{0.15} \mathrm{Ti}_{5} \mathrm{O}_{12}$ and $\mathrm{Li}_{3.8} \mathrm{Cu}_{0.2} \mathrm{Ti}_{5} \mathrm{O}_{12}$ with refinement and peak position of main phase $\mathrm{Li}_{4} \mathrm{Ti}_{5} \mathrm{O}_{12}$. 

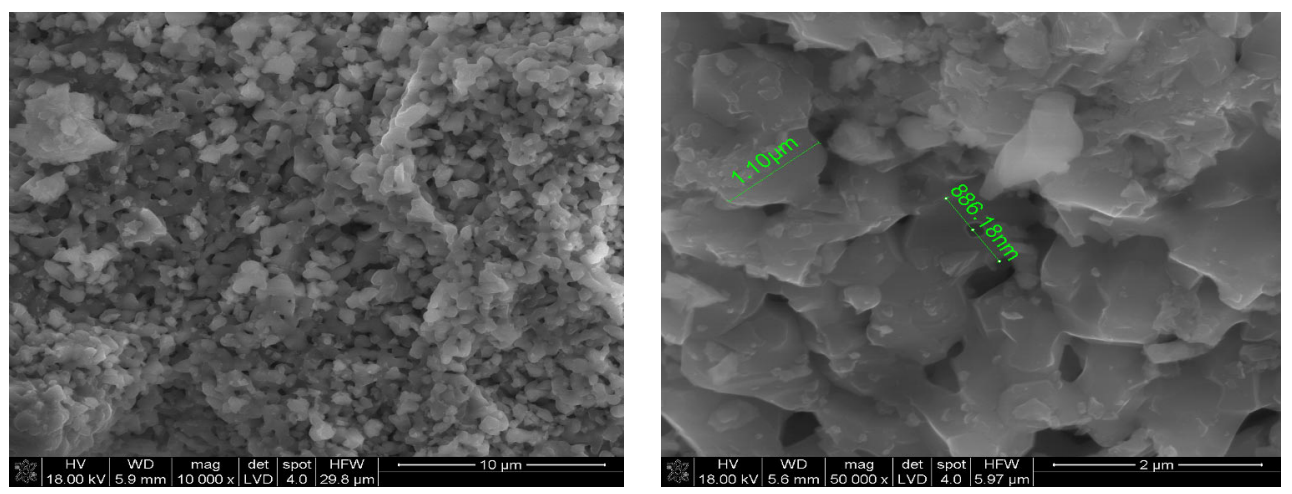

Fig. 2. SEM images of sample $\mathrm{Li}_{3.85} \mathrm{Cu}_{0.15} \mathrm{Ti}_{5} \mathrm{O}_{12}$ : magnification $\cdot 10000$ (left) and $\cdot 50000$ (right).

In order to get more structural information about the as-synthesized samples, they were also examined by SEM. Fig. 2. shows the typical SEM images of the purest $\mathrm{Li}_{3.85} \mathrm{Cu}_{0.15} \mathrm{Ti}_{5} \mathrm{O}_{12}$ powder. The morphology of this powder indicates a disordered morphology composed of agglomerated sintered particles with wide size distribution, in microscale. Some of the crystallites were aggregated in much bigger grains than average. The sintering temperature in this work is probably a little bit too high. Low sintering temperature is also crucial to prevent the grains from excessive growth. Moreover, too high sintering temperature leads to decreasing the $\mathrm{Li}$-ion transport paths. Morphology of commercial powder $\mathrm{Li}_{4} \mathrm{Ti}_{5} \mathrm{O}_{12}$ is similar to Fig. 2. images and was observed by Wang at al. [31].

\subsection{Electrochemical and transport properties}

\subsubsection{Charge/discharge performance}

Fig. 3 presents a specific capacity during discharge process for samples: a) $\mathrm{Li}_{4} \mathrm{Ti}_{5} \mathrm{O}_{12}$, $\mathrm{Li}_{3.99} \mathrm{Cu}_{0.01} \mathrm{Ti}_{5} \mathrm{O}_{12}$ and $\mathrm{Li}_{3.95} \mathrm{Cu}_{0.05} \mathrm{Ti}_{5} \mathrm{O}_{12}$ (discharge/charge current rate: $\mathrm{C} / 30, \mathrm{C} / 15$ and $\mathrm{C} / 6$ ) and b) $\mathrm{Li}_{3.9} \mathrm{Cu}_{0.1} \mathrm{Ti}_{5} \mathrm{O}_{12}, \mathrm{Li}_{3.85} \mathrm{Cu}_{0.15} \mathrm{Ti}_{5} \mathrm{O}_{12}$ and $\mathrm{Li}_{3.8} \mathrm{Cu}_{0.2} \mathrm{Ti}_{5} \mathrm{O}_{12}$ (discharge/charge current rate: $\mathrm{C} / 6,2 \mathrm{C} / 3$ and $5 \mathrm{C} / 3)$. 


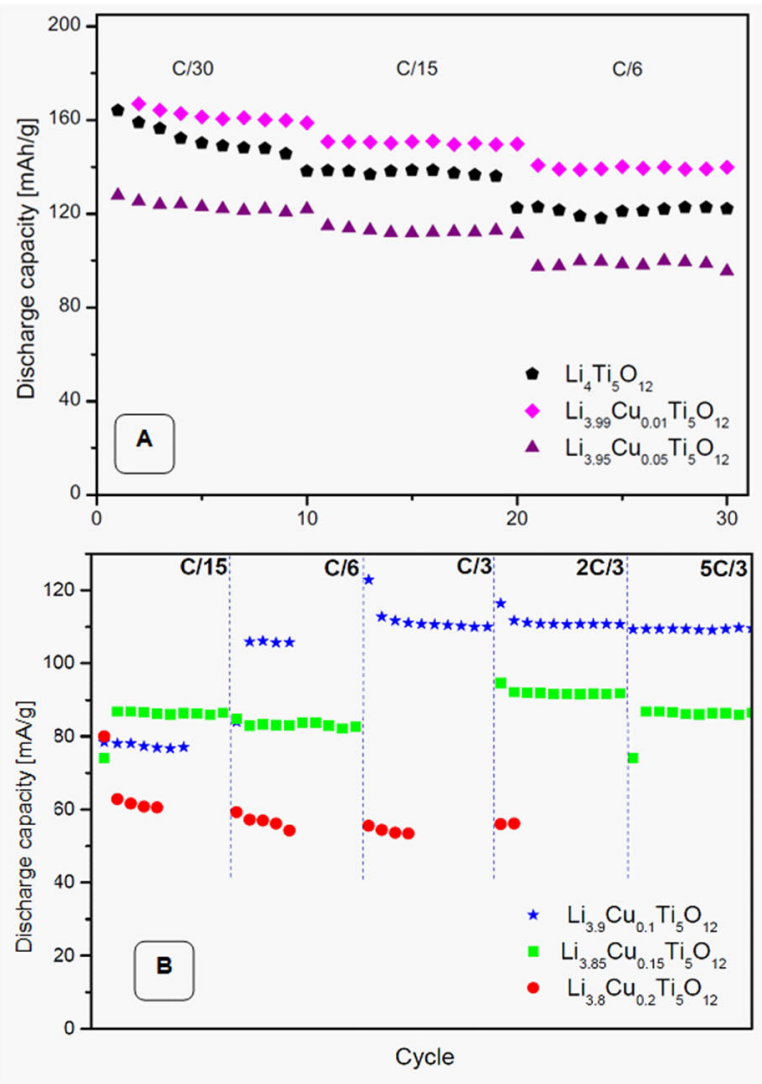

Fig. 3. Specific capacity as a function of cycle number and current rate: a) $\mathrm{Li}_{4} \mathrm{Ti}_{5} \mathrm{O}_{12}, \mathrm{Li}_{3.99} \mathrm{Cu}_{0.01} \mathrm{Ti}_{5} \mathrm{O}_{12}$ and $\mathrm{Li}_{3.95} \mathrm{Cu}_{0.05} \mathrm{Ti}_{5} \mathrm{O}_{12}$ and b) $\mathrm{Li}_{3 .} \mathrm{Cu}_{0.1} \mathrm{Ti}_{5} \mathrm{O}_{12}, \mathrm{Li}_{3.85} \mathrm{Cu}_{0.15} \mathrm{Ti}_{5} \mathrm{O}_{12}$ and $\mathrm{Li}_{3.8} \mathrm{Cu}_{0.2} \mathrm{Ti}_{5} \mathrm{O}_{12}$.

Fig. 3a shows the specific capacity from the first of 30 cycles for samples: $\mathrm{Li}_{4} \mathrm{Ti}_{5} \mathrm{O}_{12}$, $\mathrm{Li}_{3.99} \mathrm{Cu}_{0.01} \mathrm{Ti}_{5} \mathrm{O}_{12}$ and $\mathrm{Li}_{3.95} \mathrm{Cu}_{0.05} \mathrm{Ti}_{5} \mathrm{O}_{12}$, at $\mathrm{C} / 30, \mathrm{C} / 15$ and $\mathrm{C} / 6$ rates. For each sample, specific capacity significantly decreases with each next rate. Non-doped LTO has specific capacity at rates $\mathrm{C} / 30, \mathrm{C} / 15$ and $\mathrm{C} / 6$ at $\sim 150 \mathrm{mAh} \cdot \mathrm{g}^{-1}, 140 \mathrm{mAh} \cdot \mathrm{g}^{-1}$ and $125 \mathrm{mAh} \cdot \mathrm{g}^{-1}$ respectively. The $\mathrm{Li}_{3.95} \mathrm{Cu}_{0.05} \mathrm{Ti}_{5} \mathrm{O}_{12}$ sample has $40 \mathrm{mAh} \cdot \mathrm{g}^{-1}$ smaller specific capacity than the first two samples. Next three samples were tested with $\mathrm{C} / 15, \mathrm{C} / 6, \mathrm{C} / 3,2 \mathrm{C} / 3$ and $5 \mathrm{C} / 3$, current rates achieve $110 \mathrm{mAh} \cdot \mathrm{g}^{-1}$ in the best case. The $\mathrm{Li}_{3.85} \mathrm{Cu}_{0.15} \mathrm{Ti}_{5} \mathrm{O}_{12}$ and $\mathrm{Li}_{3.8} \mathrm{Cu}_{0.2} \mathrm{Ti}_{5} \mathrm{O}_{12}$ samples have very stable capacity characteristics. The best and well known sample is $\mathrm{Li}_{3.85} \mathrm{Cu}_{0.15} \mathrm{Ti}_{5} \mathrm{O}_{12}$. The cells assembled with anode based on this material show $100 \%$ of reversibility. Moreover, specific capacity measured at the first 10 cycles and after all tests, has the same value, which responds to $77 \%$ of theoretical capacity for $1 \mathrm{C}$ rate. 


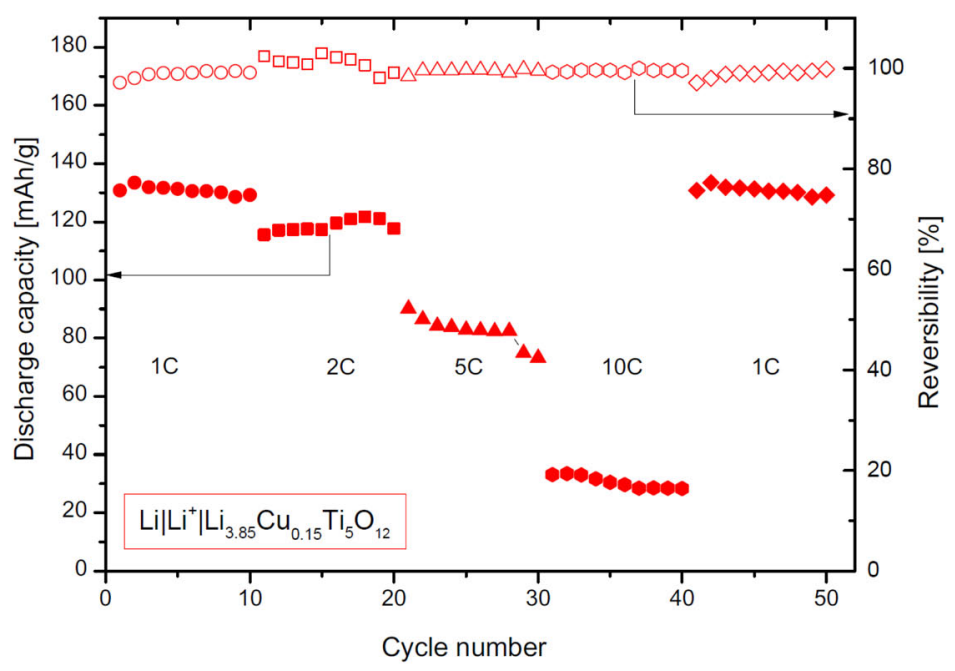

Fig. 4. Specific capacity and reversibility as a function of cycle number forLi ${ }_{3.85} \mathrm{Cu}_{0.15} \mathrm{Ti}_{5} \mathrm{O}_{12}$.

In Fig. 4 we can observe change discharge capacity of $\mathrm{Li}_{3.85} \mathrm{Cu}_{0.15} \mathrm{Ti}_{5} \mathrm{O}_{12}$ sample as a function of cycle number and charge rate. With increased the current rate, specific capacity was decreased; the value of specific capacity for $1 \mathrm{C}$ rate was $\sim 133 \mathrm{mAh} \cdot \mathrm{g}^{-1}$, and for $10 \mathrm{C}$ rate was $\sim 30 \mathrm{mAh} \cdot \mathrm{g}^{-1}$. This sample was characterized by excellent reversibility of charge/discharge process.

\subsubsection{Cyclic voltammetry}

Cyclic voltammograms and integral $\mathrm{d} Q / \mathrm{d} E$ shown in Fig. 5 a and b, respectively, were obtained with $\mathrm{Li}_{3.85} \mathrm{Cu}_{0.15} \mathrm{Ti}_{5} \mathrm{O}_{12}$-based anode in $\mathrm{Li}$-ion cell, at the different scan rates. In order to check the stability and reversibility of a process, the cell was tested at three different scan rates, each of these rates was repeated three times. As a result perfectly reversible cycles were obtained. 


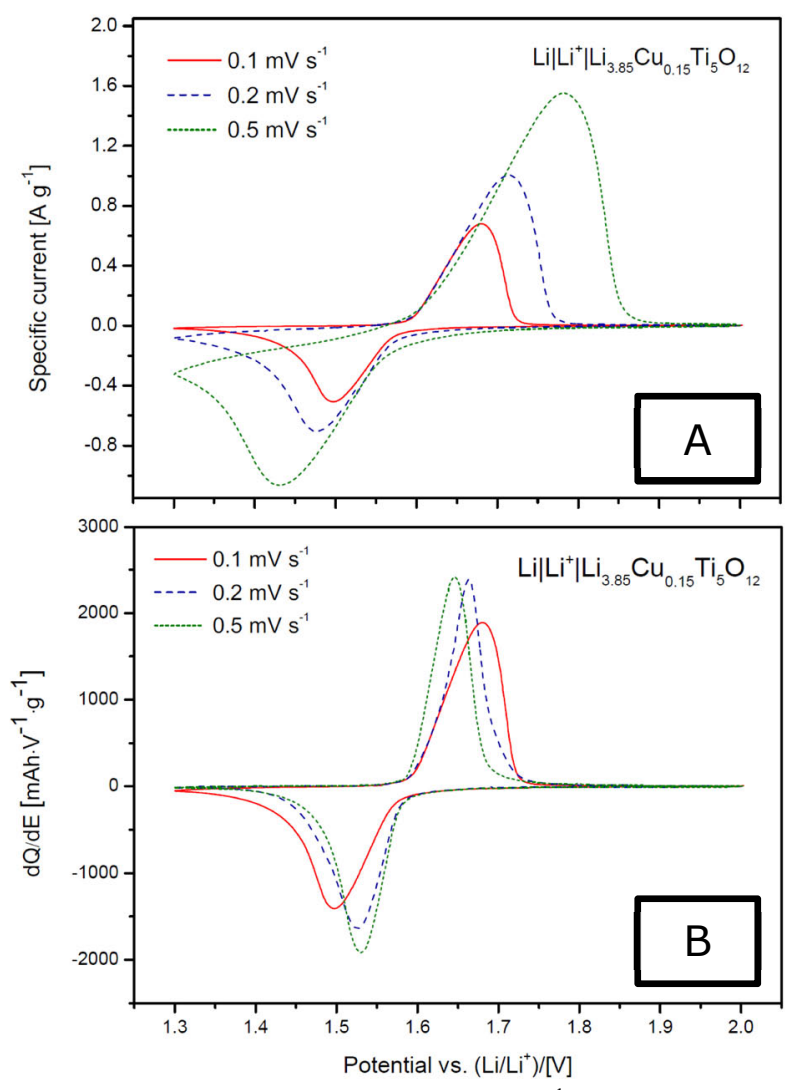

Fig. 5. Cyclic voltammograms (a) and integral $\mathrm{d} Q / \mathrm{d} E$ ) (b) of $3^{\text {rd }}$ cycles of $\mathrm{Li}\left|\mathrm{Li}^{+}\right| \mathrm{Li}_{3.85} \mathrm{Cu}_{0.15} \mathrm{Ti}_{5} \mathrm{O}_{12}$ at different scan rates.

The three cyclic voltammograms of $\mathrm{Li}\left|\mathrm{Li}^{+}\right| \mathrm{Li}_{3.85} \mathrm{Cu}_{0.15} \mathrm{Ti}_{5} \mathrm{O}_{12}$ cell are shown in Fig. 5 b. Data for the first cycle at $0.1 \mathrm{mVs}^{-1}$ scan rates indicate small polarization. However, the next cycles are very similar. At the third cycle in each scan rates, which are presented in Fig. 5., the oxidation ( $\mathrm{Li}$ deintercalation) and reduction ( $\mathrm{Li}$ intercalation) peaks are located at $1.65 \mathrm{~V}$ and $1.53 \mathrm{~V}$, respectively, with the average value being $1.59 \mathrm{~V}$. It corresponds to the voltage of $\mathrm{Ti}^{3+} / \mathrm{Ti}^{4+}$ redox couple $(1.60 \mathrm{~V})$ for $\mathrm{Li}_{4} \mathrm{Ti}_{5} \mathrm{O}_{12}$ material. The observed difference between potentials of anodic and cathodic peaks equals $60 \mathrm{mV}$. As can be seen in Fig. 5., with the increasing scan rate, potentials of anodic and cathodic peak shift slightly from each other. 


\subsubsection{Conductivity}

The impedance spectroscopy was used to study the transport properties of the samples. (Fig. $\mathbf{6} \mathbf{a}$ and $\mathbf{b})$.
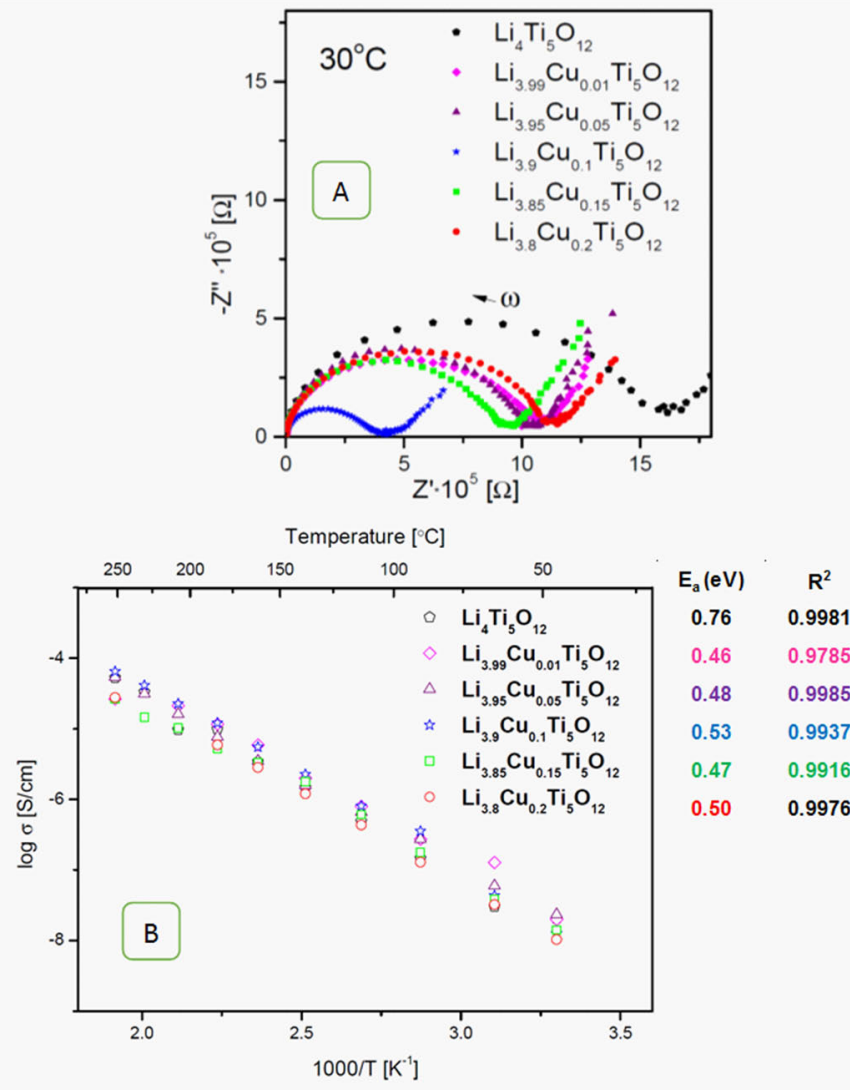

Fig. 6. Complex impedance plots of samples $\mathrm{Li}_{4-\mathrm{x}} \mathrm{Cu}_{\mathrm{x}} \mathrm{Ti}_{5} \mathrm{O}_{12}$, where $0 \leq \mathrm{x} \leq 0.2$ at $30^{\circ} \mathrm{C}$ temperature (a); temperature dependence of total conductivity for all studied samples $\mathrm{Li}_{4-\mathrm{x}} \mathrm{Cu}_{\mathrm{x}} \mathrm{Ti}_{5} \mathrm{O}_{12}$, where $0 \leq \mathrm{x} \leq$ $0.2 \mathrm{Cu}$ with activation energy of studied samples calculated by the standard Arrhenius equation (b).

Fig. 6b. shows the relationship between $\log \sigma$ and 1000/T. The activation energy of this process was presented on the right from curves. $E_{a}$ of the pellets were calculated with Arrhenius equation. $\mathrm{R}^{2}$ of calculated values are quite proper and equal $0.988 \pm 0.01$ averagely. Conductivity increases with the increase of temperature, however conductivity values are similar to each other. Undoped sample has the biggest activation energy $(0.76 \mathrm{eV}$ compared to $\sim 0.5 \mathrm{eV}$ for the others) and the biggest resistance at the same time. The pellet has resistance in the range of $15 \cdot 10^{5}[\Omega]$, this value is $50 \%$ higher from the others. The $\mathrm{Li}_{3.85} \mathrm{Cu}_{0.15} \mathrm{Ti}_{5} \mathrm{O}_{12}$ sample presents the smallest energy activation.

\section{Conclusion}

The sample of $\mathrm{Li}_{4-\mathrm{x}} \mathrm{Cu}_{\mathrm{x}} \mathrm{Ti}_{5} \mathrm{O}_{12}$, where $0 \leq \mathrm{x} \leq 0.2$ were prepared using a solid-state method. In the SEM images we can observe crystallites in width spectrum of size, due to high temperature of sintering of powders. Substitution of $\mathrm{Cu}$ in LTO slightly changes 
electrochemical performance of the material. The best electrochemical properties and reversibility during intercalation/deintercalation are presented in LTO with $0.15 \mathrm{Cu}$ molar ratio. The difference between cathodic and anodic peak in cyclic voltammograms suggests single-electron process of lithiation.

The financial support of the author Danuta Olszewska - the AGH University of Science and Technology, research project No.11.11.210.911 and Anna Rutkowska - the AGH University of Science and Technology, research project No.15.11.210.338.

\section{References}

1. M. Wakihara, Mater. Sci. Eng. Rep. 33, 109 (2001)

2. X. Guo, C. Wang, M. Chen, J. Wang, J. Zheng, J. Power Sources 214, 107 (2012)

3. Pan H, Hu Y-S, Chen L Energy Environ Sci 6, 2338-2360 (2013)

4. U.S. Department of Energy, Grid Energy Storage, 67 (2013)

5. J. Liu, X. Li, J. Yang, D. Geng, Y. Li, D. Wang, R. Li, X. Sun, M. Cai, M.W. Verbrugge, Electrochim. Acta. 63, 100 (2012)

6. C. Lin, M.O. Lai, L. Lu, H. Zhou, Y. Xin, J. Power Sources 244, 272 (2013)

7. S. Goriparti, E. Miele, F. De Angelis, E. Di Fabrizio, R. Proietti Zaccaria, C. Capiglia, J. Power Sources 257, 421 (2014)

8. T. Yuan, K. Wang, R. Cai, R. Ran, Z. Shao, J. Alloys Compd 477, 665 (2009)

9. D. Wu, Y. Cheng, Ionics (Kiel). 19, 395 (2013)

10. J. Liu, X. Li, M. Cai, R. Li, X. Sun, Electrochim. Acta 93, 195 (2013) 195-201.

11. E. Pohjalainen, S. Räsänen, M. Jokinen, K. Yliniemi, D.A. Worsley, J. Kuusivaara, J. Juurikivi, R. Ekqvist, T. Kallio, M. Karppinen, J. Power Sources 226, 134 (2013)

12. X.-D. Zheng, C.-C. Dong, B. Huang, M. Lu, Ionics (Kiel). 19, 385 (2012)

13. C. Lai, Z. Wu, Y. Zhu, Q. Wu, L. Li, C. Wang, J. Power Sources 226, 71 (2013)

14. Y. Zhang, L. Wu, J. Zhao, W. Yu, Mater. Chem. Phys. 166, 182 (2015)

15. S.H. Yu, A. Pucci, T. Herntrich, M.G. Willinger, S.H. Baek, Y.E. Sung, N. Pinna, J. Mater. Chem. 21, 806 (2011)

16. Z. Liu, N. Zhang, Z. Wang, K. Sun, J. Power Sources 205, 479 (2012)

17. M. Li, J. Liang, X. Wang, K. Yu, J. Alloys Compd 681, 471 (2016)

18. Z. Zhang, G. Li, H. Peng, K. Chen, J. Mater. Chem. A. 1, 15429 (2013)

19. W. Fang, X. Cheng, P. Zuo, Y. Ma, L. Liao, G. Yin, Solid State Ionics 244, 52 (2013)

20. Y. Xu, G. Jian, M.R. Zachariah, C. Wang, J. Mater. Chem. A. 1, 15486 (2013)

21. Q. Zhang, X. Li, Int. J. Electrochem. Sci. 8, 6449 (2013)

22. E.D. Jeong, H.J. Han, O.S. Jung, M.G. Ha, C.H. Doh, M.J. Hwang, H.-S. Yang, K.S.S. Hong, Mater. Res. Bull. 47, 2847 (2012)

23. C. Lin, X. Fan, Y. Xin, F. Cheng, M.O. Lai, H. Zhou, L. Lu, J. Mater. Chem. A 2, 9982 (2014)

24. Z. Zhao, Y. Xu, M. Ji, H. Zhang, Electrochim. Acta 109, 645 (2013)

25. S. Ji, J. Zhang, W. Wang, Y. Huang, Z. Feng, Z. Zhang, Z. Tang, Mater. Chem. Phys. 123, $510(2010)$

26. C.-C. Yang, H.-C. Hu, S.J.J. Lin, W.-C. Chien, J. Power Sources 258, 424 (2014)

27. C. Lin, B. Ding, Y. Xin, F. Cheng, M.O. Lai, L. Lu, H. Zhou, J. Power Sources 248 , 1034 (2014)

28. C. Larson, R.B. Von Dreele, Structure 748, 86 (2004)

29. B.H. Toby, Powder Diffr. 21, 67 (2006)

30. B.H. Toby, J. Appl. Crystallogr. 34, 210 (2001)

31. W.Wang, D. Choi, Z. Yang, Metal. Mat. Transactions A 44, supp. 1, 21 (2013) 